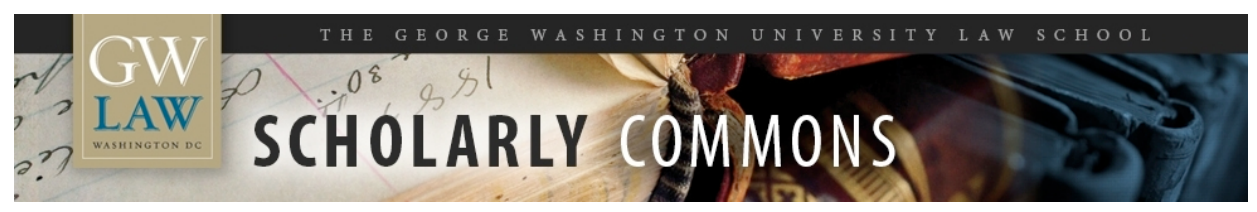

\title{
A User's Guide to Proposals to Replace the U.S. Tax System and Strangle Fiscal Policy
}

Neil H. Buchanan

George Washington University Law School, neilhbuchanan@gmail.com

Follow this and additional works at: https://scholarship.law.gwu.edu/faculty_publications

Part of the Law Commons

\section{Recommended Citation}

Neil H. Buchanan, A User's Guide to Proposals to Replace the U.S. Tax System and Strangle Fiscal Policy, $33 \mathrm{~J}$. of Econ. Issues 505 (1999).

This Article is brought to you for free and open access by the Faculty Scholarship at Scholarly Commons. It has been accepted for inclusion in GW Law Faculty Publications \& Other Works by an authorized administrator of Scholarly Commons. For more information, please contact spagel@law.gwu.edu. 
A user's guide to proposals to replace the U.S. tax system and strangle fisca...

\section{Neil H Buchanan}

Journal of Economic Issues; Sep 1999; 33, 3; ABI/INFORM Global

pg. 505

\section{A User's Guide to Proposals to Replace the U.S. Tax System and Strangle Fiscal Policy}

Neil H. Buchanan

Taxes evoke strong and contradictory emotions. The desire to keep as much money as possible conflicts with the sense that we should contribute to the good of society. Respect for privacy collides with the need to ensure that others are paying their fair share. Dislike of complexity clashes with the desire to be responsive to unique situations. Given this fundamental ambivalence, it is not surprising that the tax system is a constant target of revision.

As the 1998 midterm elections fade into memory and the presidential election looms in 2000, tax "reform" will again be the order of the day. Anti-tax rhetoric such as "confiscatory tax rates," "punishing success," and "a penalty on the creation of wealth," as well as the all-purpose reactionary insult "social engineering," will fill the airwaves.

While many tax proposals are offered piecemeal, such as reducing or eliminating specific types of levies, the recent trend in the United States (at least among presidential aspirants) has been to think big and to propose The Perfect Tax System. There are no new proposals, of course. Instead, rewrapped packages arrive containing the same old proposals to shift taxation away from corporations and wealthy individuals and toward everyone else. ${ }^{1}$ As an expression of the belief that these new systems really are perfect, many proposals are also spiked with constitutional provisions to make future changes in the tax system more difficult.

As a matter of political marketing, promoters stress each proposal's greater simplicity relative to the current system. ${ }^{2}$ Most are also claimed to increase the rate of national saving. Both of these effects (simplicity and saving-friendliness) will supposedly lead to greater investment, higher levels of long-term economic growth,

The author holds a Ph.D. in Economics from Harvard University. 
higher standards of living, and greater international competitiveness. These claims are, of course, specious. On this, readers of this journal might refer to Buchanan [1999].

This paper provides descriptions of the four prototypes for extreme tax restructuring that have become popular in U.S. policy circles: direct consumption taxes, saving-exempt taxes, labor-income taxes, and simplified income taxes. ${ }^{3}$ While some reference to specific proposals offered in Congress over the last several years will be useful, the analysis will generally emphasize concepts over administrative details.

In addition to rebuilding the federal tax system, many proposals would cement the new arrangements with special constitutional and legislative provisions. These proposals -and their interactions with other aspects of the tax code-are the focus of the second section of the paper.

Moving from description to critique, the third section dissects three familiar arguments that underlie all but one of the four proposals. We are told that we are over-taxing capital, that we should eliminate "double-taxation," and that the tax system should be designed so that it does not "distort" the economy. These arguments are, at best, half-truths; and they are more likely dishonest rationalizations for a massive upward redistribution of income. They certainly do not add up even to a minimal case for fundamental tax restructuring.

\section{Outlines of the Major Approaches to Tax Restructuring}

As noted above, current discussions of sweeping tax restructuring in the United States generally revolve around four prototypes: direct consumption taxes, savingexempt taxes, labor-income taxes, and simplified income taxes. The differences among the first three are largely cosmetic but are politically important. Each of the three is designed to encourage saving by taxing consumption exclusively. All four systems will be described in turn below.

\section{Taxes on Consumption}

Value-Added Taxes (VATs), common in Europe and elsewhere, are business taxes that are levied at each stage of the production process. Each participant in every production process pays a certain percentage of the difference between the cost of their inputs and the revenue from their outputs.

In a pure VAT, the tax would be levied on all products, including investment goods. In that sense, the VAT is not inherently a tax on consumption. Therefore, since most proponents of the VAT intend it to work as a tax on consumption, they must make sure that the tax is not levied on the items that they wish to favor. The only way to make the VAT "investment friendly" is to create an exemptions list, 
which itemizes those goods not subject to tax or that will be subject to preferential tax rates. In practice in Europe, this has resulted in a bewilderingly complex system. Unlike sales taxes, VATs are not added to the sales price at the cash register, but are already included in the price, so a consumer does not know whether an item is tax-preferred or not. The VAT hides these political choices from the voters.

A practical problem with the concept of the value-added tax is that the term is too broad to be useful. Virtually any tax system can be called a "modified" VAT. For example, the flat tax (discussed below) has been described as "precisely a value-added tax, plus a rebate of taxes to families based on their labor income and family size" [Slemrod 1995]. Most people think of a VAT as being equivalent to a national sales tax, when in fact a national sales tax is merely one type of VAT.

Other than the income tax, perhaps the most familiar tax to most Americans is the sales tax. Repealing the entire tax code and replacing it with a national sales tax has become a potential goal of several prominent politicians, the most politically powerful of whom is House Ways and Means Committee Chairman Bill Archer (RTexas).

Of course, the basic issue in tax policy does not disappear with a national sales tax. The difficult political decisions (and the complexity) will come when the tax base is defined. Should educational expenses be taxed as consumption or exempted as investment in human capital? What about preventive personal health care? These decisions would be the grist of tax debates for future elections, just as discussions of personal exemptions and exclusions dominate policy debates today.

\section{Saving-Exempt Taxes}

VATs and sales taxes are designed to tax consumption, specifically so that they will encourage saving - which is wrongly assumed to be the same as encouraging investment. It is also possible to promote saving much more explicitly by simply telling people that they will pay no taxes on income that they put into savings vehicles. In this category, it is useful to discuss the details of a specific proposal, the "USA Tax," because it is one of the only proposals that has been offered as a complete piece of legislation. While it certainly will never be adopted in its original form, it provides many useful concepts and details that can frame the discussion.

Originally proposed by former Senator Sam Nunn (D-Ga.) and Senator Pete Domenici (R-N.M.), the USA Tax (Universal Saving Allowance Tax) is essentially a "universal IRA" plan. It allows people to put as much money as they want into a saving vehicle and not pay taxes on that money until they withdraw the money at a later date. If a person earns $\$ 20,000$ and saves none of it, therefore, they would pay the same in current taxes as a person who earns $\$ 50,000$ and saves $\$ 30,000$ of it. The rate structure can be as progressive or regressive as one wants it to be. For the 
USA Tax, there are three rates: 15,20 , and 40 percent. On the business tax side, the USA Tax would levy a single tax rate of 11 percent on net cash flow.

The rate structure for personal taxes is actually less graduated than it appears, since the USA Tax would allow deductions for payroll taxes (Social Security and Medicare). With these credits included, the three rates are reduced to 11 percent (for taxable income up to $\$ 5,400$ for married filers), 19 percent $(\$ 5,400-\$ 24,000)$, and 32 percent $(\$ 24,000$ and over). With the cutoff points as low as they are, moreover, the progressivity of the system would be much less than even the top rate of 32 percent would imply, since larger and larger portions of income would be saved (and thus untaxed) as personal income rises.

Take, for example, a person with $\$ 50,000$ in gross income and $\$ 25,000$ in taxable income (after subtracting family exemptions, savings, college tuition, mortgage interest, and charitable contributions). If that person earned and consumed another $\$ 1,000$, their tax bill would rise by $\$ 320$ because their marginal tax rate is 32 percent. On the other hand, if a higher-income person earned an extra $\$ 1,000$, it is much more likely that they would save much or all of it, meaning that they will pay lower taxes on their marginal income. The difference in tax treatment implies that the middle-income person would face a higher tax rate merely because he or she has not reached the point where consumption spending has leveled off. By supply-side logic, then, that implies a relative work disincentive for the person whose consumption needs are the most immediate, since his or her effective tax rate is higher.

The USA Tax retains the deductions for mortgage interest and charitable contributions while it eliminates the deductions for state and local taxes. Significantly, however, it introduces a "higher education" deduction, treating expenditures for tuition at colleges and universities, junior colleges, and various technical training schools as an expensable investment, rather than consumption.

If for no other reason, therefore, the USA Tax is significant in including such a straightforward incentive to invest in human capital, a feature that is sadly lacking from the current tax code and in all of the other proposals. Of course, this need not be part of a saving-exempt tax at all. However, it nicely illustrates just how easy it is to load both good and bad details onto a supposedly simple approach.

\section{The Flat Tax}

Taxes on labor income provide a different angle on taxing people, rather than machines. The most famous of these is the Flat Tax. A flat tax applies only to labor income (wages and salaries) and does not tax personal income from property (interest, dividends, or capital gains). On the business side, taxes are levied on net cash flow, i.e., business revenue after subtracting all expenses for wages, benefits, and investment. This effectively means that all investment spending is fully expensed, 
that is, 100 percent depreciated and deducted in the year that it is incurred. The tax rate is the same for both individuals and businesses.

Most flat tax plans are based on the proposal by Robert Hall and Alvin Rabushka [1995], who have been marketing this idea in one form or another for almost two decades. The Hall/Rabushka approach is "pure" in the sense that there are no further exemptions for specific items. However, in a bow to political reality, most flat tax proponents in Congress would maintain the deductions for mortgage interest and charitable contributions. To pay for those deductions, a revenue-neutral plan must offer a combination of lower basic exemptions and/or a higher flat rate on all taxable income. Revenue neutrality requires the tax rate to be roughly 21 percent [Gleckman and McNamee 1996], although most politicians claim that the rate will be in the mid-teens. ${ }^{4}$

One of the most dishonest features of the Flat Tax is the name itself. By drawing attention to the single tax rate that is part of most such proposals, the public is led to believe that the complexity of the current tax code is caused by its graduated rates. This is patently absurd. The current tax code would be no simpler than it is today if the five tax brackets were replaced by one rate. (How difficult is it to look up tax liability in a tax table? The complexity comes in actually computing the number to look up in that table.) Similarly, any flat tax could include graduated rates without changing any other aspect of the system.

The best Hall and Rabushka can come up with to justify the single rate is that multiple rates encourage income shifting, as taxpayers would supposedly try to make their incomes subject to the lowest rate possible. Currently, for example, corporate executives prefer to take their incomes in the form of capital gains (from stock options), rather than salary, since the tax rate on capital gains is half of the rate for earned income. However, this is only true if different sources of income are taxed at differing rates. Under a graduated tax schedule, high-income individuals could still be liable to pay taxes at a 40 percent rate for all of their income, while middle-class people could be liable to pay taxes at a 15 percent rate. No income shifting games would be possible.

This refusal to consider the possibility of graduated rates-indeed, the insistence on calling this the Flat Tax-exposes the true agenda behind this proposal: shift the tax burden downward. Of course, the sponsors of flat tax plans claim that the overall effect of their systems would be progressive despite their flat-rate structure-due to the large exemptions that reduce the proportion of income subject to tax. In virtually all flat tax plans offered to date, the single tax rate is applied to all labor income minus a basic exemption (on the order of $\$ 20,000$ for individuals).

Nevertheless, it is worth remembering that these plans are still committed to the notion that the maximum marginal tax rate on any level of income should be no more than a certain low percentage. This means that the country would be moving to a system in which a person with a million dollars in annual income would find 
their next dollar of labor income taxed at a maximum of, say, 17 percent instead of the current 39.6 percent. $^{5}$

A flat tax does not exempt saving itself from taxation; instead, the income one earns from saving and investment is exempted from tax. Thus, the "cost of saving" is decreased (or, equivalently, the cost of consumption is increased) at the individual level, as one can earn a greater after-tax rate-of-return on any amount of saving at a particular interest rate. (Hall and Rabushka also claim that the plan itself would lower interest rates.)

More to the point, the action on the Flat Tax happens at the business end, as overall taxes on capital are reduced significantly. Even here, however, the story is not as clean as it seems, since different industries would experience wildly different changes in their tax liabilities. For example, aircraft makers would pay 1.4 percent more of their income in taxes, while automobile makers would pay 0.4 percent less [Merrill, Wertz, and Shah 1995].

Finally, the Flat Tax, despite the claims of its proponents that it is a completely worked-out plan, still has one major gap. Even after years of analysis and discussion, proponents of the Flat Tax do not know how they would tax financial services [Gleckman and McNamee 1996]. That is, how does one tax "net cash flow" when it is unclear what to include as revenues for companies whose business it is to turn over large flows of cash? Certainly, a bank's revenues could not include all of its deposits, since it is merely holding that money for someone else. Therefore, it is not at all clear how the flat-taxers would tax banks or other financial corporations. This ought to be, to say the least, a matter of some concern for anyone who would suggest that the country should rewrite its entire tax code in favor of a flat tax. ${ }^{6}$

\section{Keeping the Income Tax but Sweeping out the Stables}

A simple alternative to these reactionary plans is to keep the basic structure that we have now but to eliminate all of the complexity of the tax code by eliminating all deductions. ${ }^{7}$ To date, the only detailed plan for fundamental change in the tax code that maintains an emphasis on income taxation was proposed by House Minority Leader Richard Gephardt. He calls his proposal the "10\% Tax Plan," which is something of a misnomer, since it has more than one tax bracket. It is an attempt to remove the complexity from the current tax code, thus expanding the tax base and lowering tax rates-while maintaining a progressive rate structure and a commitment to tax all income.

Under this plan, ${ }^{8}$ all income, both earned and unearned, would be taxable for a majority of taxpayers at a 10 percent rate. At relatively high incomes $(\$ 40,200$ of taxable income for a family of four, after subtracting $\$ 19,350$ in exemptions, i.e., a gross income of $\$ 59,550$ ), the marginal tax rate rises progressively to $20,26,32$, and finally 34 percent for taxable income of more than $\$ 264,450$. The only deduc- 
tion that would be maintained is the mortgage interest deduction. The plan is relatively mute when it comes to business taxes, with the exception of a few smaller items like personal deductions for job-related expenses (which are reclassified as adjustments to income).

This plan is generally not implicated in most of the discussion below. However, it is the only progressive tax plan that has yet been seriously proposed, so it is worth mentioning simply as an alternative to the regressive plans.

\section{Making Future Change More Difficult}

One of the principle goals of economic policy is to create prosperity, preferably in both the immediate and longer-term senses. Part of the approach to achieving that goal should be to maintain maximum flexibility in policymaking, that is, to keep all policy options open. Circumstances will change, so forsaking certain policy options ahead of time is surely foolish.

\section{Super-Majorities and Referenda}

The paranoid (and mistaken) belief that legislators are simply salivating in their desire to raise taxes surreptitiously has spawned a set of anti-democratic and self-defeating proposals-many of them offered as constitutional amendments. Even Rep. Gephardt has proposed that a national referendum be held before any of the tax rates in his plan could be increased. Others have proposed super-majority requirements in both houses of Congress before taxes could be raised by any means (increases in rates, changes in exemptions, etc.). In some proposals, for example, more than twothirds of both houses would have to approve any tax increase-which effectively means that either 34 senators or 146 representatives could prevent any tax change that would increase revenues.

The problem with these extraordinary requirements is that they can create rigidities in both directions. For example, in response to downturns in the economy, we should want to cut taxes-and to do so in a timely fashion. This seems easy enough, since no one has proposed procedural impediments to cutting taxes. The problem is that everyone will know that taxes, once cut, cannot be increased again without a huge expenditure of political capital. Since many in Congress and elsewhere are (perversely) committed to maintaining a balanced federal budget, the difficulty of raising taxes would be a potent reason to hesitate before cutting taxes-even in a downturn. Therefore, the likely result is that taxes would not be changed in either direction, except in extreme circumstances.

The various proposals are silent on this matter, but it is not necessarily clear that one could even pass a tax cut with a "sunset" clause in it. For example, one might 
propose the following: "Taxes will be decreased tomorrow and then increased back to their current level one year from tomorrow. "If this were to pass by less than a super-majority vote, there might be a legal challenge to the ability to "raise taxes" in the future, even if taxes are only to be raised back to their previous level.

Moreover, this logic does not apply solely to cyclical changes in the economy. If the economy were to start growing faster in a sustained way, we would normally believe that the higher-than-expected tax revenues should either be spent on previously ignored projects or reduced by enacting a tax cut. Should there be a supermajority requirement, however, any deficit-fearing member of Congress would not want to cut taxes, because the seeming improvement in the economy could prove to be short-lived. After all, even professional economists have difficulty distinguishing a cyclical upturn from a secular trend.

Only two possibilities would remain: either allow excess tax revenues to be a drag on the economy or spend the excess on whatever projects might be handy (since spending would not be required to fall under a super-majority rule-at least, not yet). Ironically, therefore, the results of a super-majority rule might be to decrease the likelihood of tax cuts in both good times and bad and to increase the level of government spending.

The final problem with the super-majority proposals involves what type of tax change is covered by the super-majority requirement. For example, a proposal by the so-called Kemp Commission [National Commission on Economic Growth and Tax Reform 1996], which would require a two-thirds majority vote in both the House and the Senate, applied only to proposals to raise the single tax rate itself.

This should hardly be comforting to anyone concerned about rampant taxation. Recall that the Flat Tax creates mild de facto progressivity by including a large standard deduction. Since the standard deduction would not be subject to the commission's super-majority requirement, the easy way to raise taxes would be to decrease or eliminate the standard deduction. Perhaps not coincidentally, this would raise more taxes from the lower-middle class and the poor. Therefore, the system would be biased toward generating future regressivity.

This has encouraged efforts to create "loophole-free" tax limitation plans. One proposed constitutional amendment would impose a super-majority requirement on any law that would even indirectly increase federal tax revenue. ("Any bill, resolution, or other legislative measure changing the internal revenue laws shall require for final adoption in either House the concurrence of two-thirds of the members present, unless that bill, resolution, or measure is determined at the time of adoption, in a reasonable manner prescribed by law, not to increase the internal revenue by more than a de minimis amount" [Barton 1996].) As proposed, it is not clear whether such an amendment would even permit offsetting tax changes (two or more proposals that, on net, would leave tax revenue unchanged) to be passed by a simple majority. This means that any tax proposal that would raise revenue, whether a di- 
rect rate increase or an obscure definitional change that would broaden the tax base, could only be passed by a super-majority vote.

Beyond the nightmarish details involved with such a broad proposal, there is a much broader problem with such a plan. Supply-side economists (who are among those most anxious to reduce taxes on businesses and the wealthy) claim that tax rate cuts cause tax revenue increases. The famous "Laffer Curve" was designed, after all, to demonstrate that the government could receive more tax revenue by lowering the tax rate.

Whether or not one believes that particular assertion, the argument comes up again and again, from debates about capital gains taxation at the national level to arguments over property tax rates at the local level. In almost every case, one can find conflicting forecasts of both increases and decreases in tax revenue due to any proposed change in tax law. Indeed, Alan Auerbach [1996] points out that so-called "dynamic scoring," which is supposed to include the effects on tax revenues of behavioral changes due to changes in tax policy, is unworkable because even the sign of the behavioral effect is unknowable.

If, as many proponents claim, a cut in the capital gains tax rate will increase tax revenue, then that proposal would require a super-majority vote. In that bizarre world, proponents of various changes in the tax code would be inspired to present evidence that their proposals will be revenue losers, which would allow them to be passed by simple majorities. The current debates would be turned upside down, with proponents of higher tax rates adopting Laffer Curve-style analyses to ease passage of their proposals.

\section{Interactions with Budget Rules}

If a super-majority requirement were enforced in conjunction with a constitutional amendment requiring a balanced budget, the situation would become murkier still. If a balanced budget amendment required a super-majority vote to set aside the requirement of a balanced budget (as most proposed versions of the amendment would do), then any change that would increase the deficit would require a supermajority vote. Tax law changes that forecast a decrease in tax revenue would then fall under that dragnet. In other words, no fiscal policy-no matter what its imagined effects on revenues-could ever be changed without a super-majority vote.

This would certainly further paralyze the political system. Nothing could be changed without a super-majority vote. Anyone opposed to any change need only show that the change has some effect on the federal fiscal system. For those who believe that a perfect fiscal system (so perfect that it will never need to be changed) can be put in place before these proposals become part of the Constitution, this might be the desired result. For others, however, the prospects are disheartening at best. 
It is even possible that the system could completely break down. If the result of not changing the tax laws is to increase revenues, that too could be challenged as a "tax increase" that needs to be subjected to a super-majority vote. Thus, given the lack of ability to forecast revenues with any precision, there would be no "default" position. Any alternative, including the choice to stand pat, would be open to a constitutional challenge.

The only technical alternative to this would be to designate a particular agency that would make definitive forecasts for every policy initiative-forecasts that would have to be legally immune from challenge. This would further dilute the decisionmaking power of elected representatives.

Moreover, any such agency would be forced to institutionalize a single model of the economy. This would certainly be controversial among both economists and politicians, no matter which approach was chosen, since the economics profession is extremely split in its opinions about various approaches to modeling. Which version of Keynesianism or neoclassicism will be the "official" arbiter of economic policy? The possibilities for dispute and conflict are seemingly endless.

The overall conclusions regarding special voting rules are (1) if they apply only to changing the tax rate in a single-rate system, the result is inherently regressive; (2) if they apply to the rates but not to the base, they are easily sidestepped; (3) if they apply to the base as well as the rate(s), it is extremely difficult to define what a "tax increase" is, leading to more gamesmanship; and (4) in conjunction with a balanced-budget amendment (or a binding balanced-budget requirement), the super-majority requirement for tax increases will lead to legislative stasis.

\section{The (Lack of) Reasoning Behind the Proposals}

The proposals described above are, in some ways, entirely political creations. However, the underlying themes have a familiar ring, at least to those of us who have had contact with neoclassical economics. The basic argument underlying all neoclassical tax analyses is this: All taxes are inefficient, but taxes on capital are the worst of all. This section reviews the specific arguments that attempt to justify shifting taxes away from capital and toward working people.

\section{Cutting Taxes on Capital (Entirely?)}

On the empirical level, some interesting work has been done by economists who have attempted to apply the neoclassical model to actual U.S. data, testing whether cuts in taxes on capital will have the purported benefits. Steven Fazzari and Benjamin Herzon [1996] reach particularly devastating conclusions. Using a rather standard neoclassical model, and looking at the consequences of cutting the tax rate 
on capital from 28 percent to 19.8 percent, they actually confirm the orthodox conclusion that this would increase the level of GDP. However, the increase is hardly breathtaking. GDP would rise (as a result of the capital gains tax cut) by the amount that it currently rises in about a month.

Moreover, even this minimal effect must be put into perspective: (1) this is a one-time effect on GDP, not a permanent increase in the GDP growth rate; (2) even this trivial effect would take about 10 years to show up in the economy; and (3) even these tiny effects are based on highly generous estimates of the response of investment to a drop in the cost of capital. On the latter point, Fazzari and Herzon use an estimate that a 1 percent drop in the cost of capital will cause a 0.5 percent increase in the equilibrium level of the capital stock. In a rather dramatic understatement, they note that this is on the high side of the estimates reported in other economists' work.

More accurately, other studies indicate that the response of investment to declines in the cost of capital is probably zero (see Buchanan [1999] for extensive references to these studies). Therefore, the range of estimates for this effect is not between, say, 0.4 and 0.5 , so that Fazzari and Herzon's choice of the higher estimate is arguably unimportant. Instead, the range is between 0.5 and 0.0 , with the broad consensus hovering around the latter figure. The conclusion that there will be a one-time increase in GDP of 25-50 days growth therefore should be seen as an extreme upper bound, rather than as the midpoint of a range.

Empirical evidence also argues for extreme skepticism about other proposals to reduce the tax rate on capital. For example, the Investment Tax Credit, which is often used as an alternative to capital gains tax cuts, is equally unproven in creating more investment, as demonstrated by Thomas Karier [1994] and noted by Peter Clark [1993].

The common theme between all such studies is that they are looking at the results of reducing the cost of capital (through various methods). Since investment is not responsive to the cost of capital, it should not be surprising that the different methods of lowering the cost of capital are ineffective.

Moreover, it is not at all clear that capital is overtaxed in the United States, relative either to our own past or to other industrialized countries. Jane Gravelle [1994], for example, argues that aggregate effective tax rates on capital in this country have not gone up since the enactment of the landmark 1986 tax act. She writes [1994, 24]: "Thus, the claim for a need to lower capital income tax burdens on the grounds that increases in the 1986 Tax Reform Act were excessive is not supported by this measure of the effective rate." Earlier, she notes that rates of capital income taxation are now as low as they have ever been in the United States, and in particular, as low as they were in the prosperous 1960s.

For international comparisons, Dale Jorgenson and Ralph Landau [1993] present estimates of effective tax rates for 1980, 1985, and 1990 from the major industrial- 
ized countries. They show that the effective tax rates on individual assets in the United States (as elsewhere) went up and down dramatically over that decade. For example, the effective marginal tax rate on tax-exempt institutions went from 4.2 percent to -1.2 percent to 16.9 percent in the three time periods noted. Also, most types of capital had a lower effective tax rate in the United States in 1985 than in 1980 or 1990, without any demonstrable jump in investment in the 1985-89 period, relative to the other two periods (even though there was no recession in the late eighties). Finally, the effective tax rate in the United States on key assets is comparable to the rates for our two major competitors. For example, the effective marginal tax rate on machinery is (using similar assumptions to produce estimates for each country) 33.5 percent in Japan, 39.8 percent in Germany, and 38.9 percent in the United States. The United States is hardly noncompetitive.

The fact that empirical studies have failed to find an impact from changing the tax treatment of capital on rates of investment is easier to understand if one looks more carefully at related theoretical work. A great deal of effort has gone into making the assumptions of neoclassical tax theory more realistic. For example, various studies have extended the simple model by allowing agents to have different preferences with regard to present versus future consumption and by introducing the concepts of risk and uncertainty into the models.

Studies of this type have shown that, even in theory, the effect of lowering taxes on capital is ambiguous in terms of its effects on economic efficiency. Gravelle [1994] notes that any change in the tax system that favors capital income will simultaneously result in changes in other taxes, spending, and deficit levels. How these other changes will effect the economy is entirely ambiguous. In fact, Gravelle shows several theoretical specifications in which efficiency is increased by raising taxes on capital.

Given this, it is not at all clear that moving to a supposedly capital-friendly approach will have the desired positive effects-quite aside from the many negative effects of the various proposals.

\section{Double-Taxation}

The notion of double-taxation has become a central point of concern for many tax analysts. (See Hall and Rabushka [1995] for a diatribe on this subject.) In its most limited form, double-taxation describes the levying of a corporate income tax on firms, followed by a personal income tax on any dividends. The term has now become, however, a much more broad complaint about the entire tax system.

Analysis of double-taxation should be separated into two parts. First, one would want to know the total effective tax rate on any particular flow of money. Second, one should also be concerned with whether any particular method of collecting taxes creates unwanted inefficiencies. 
On the first question, it should be clear that what matters is not how many times something is taxed, but rather how much total tax is paid. Most people would, no doubt, rather pay $\$ 50$ in tax four times than pay $\$ 1,000$ in tax once. As the very orthodox analyses by Gravelle and Jorgenson and Landau noted above indicate, the effective tax rates on capital in the United States are not high. They are obviously not equal to the sum of the corporate profits tax rate (34 percent) plus the marginal tax rate on personal income (39.6 percent for most holders of significant amounts of stock). Not surprisingly, the complexity of the tax code works in favor of capital in this regard, reducing the net tax rate significantly. ${ }^{9}$

Much more important are the efficiency effects of double-taxation, which have been the subject of an extensive literature (reviewed very well by Gravelle). While there is little agreement about the overall efficiency effects of these tax artifacts (especially the size of any such effects), it is most likely the case that there are some inefficiencies of this sort caused by the tax system. However, these need to be weighed against the costs of changing the entire tax system. Using them as an excuse to replace the whole system is simply inappropriate.

It is also true that multiple taxation is not limited to capital income. Currently, labor income is taxed by the federal government twice-once by the Social Security system and once by the income tax. (One could even argue that there is triple-taxation, if one includes employers' contributions to Social Security.)

Even the transition to a consumption tax would create a severe case of doubletaxation. In the years when there is still an income tax, people pay tax on their incomes. However, anyone who puts some of their remaining money into a mutual fund, then withdraws the proceeds and spends them after the changeover to the consumption tax, would pay tax on that money again. Double-taxation would be part of the system so long as anyone had money on deposit from before the tax regime changed. ${ }^{10}$

Therefore, the preoccupation with the double-taxation of capital income is clearly not motivated by a desire to end multiple taxation. It is simply the typical Trojan horse for regressive tax changes. However, we should make no mistake about it. There is such a thing as double-taxation. It occurs whenever the same activity is taxed more than once. Therefore, profits are certainly double-taxed, as profits to businesses and as dividends to shareholders. Even if the net tax rate on capital is not too high as a result of this, why should the tax system be designed in this way?

There are two answers to this question, both of which are too practical to show up in a textbook. The first is that there is virtually no chance that double-taxation could be eliminated in a neutral fashion. That is, it is highly improbable that a political coalition could be formed that would agree to eliminate one of the two taxes while simultaneously raising the other tax rate to the appropriate level. Second, there are very good reasons to split a tax into parts, if (as is certainly the case) tax 
evasion cannot be completely eliminated. Hiding a gain twice is more difficult than hiding it once; so even if the tax system only catches the gain at one point and not the other, at least some tax revenue will be collected. This is not elegant, but it works.

More broadly, the language of double-taxation can be applied to virtually any situation. Since the economy is a system of flows-incomes flowing to households and businesses, deposits and withdrawals flowing into and out of financial institutions-one can describe nearly anything as multiple taxation by looking at the history of the transaction. A business can claim that any business tax amounts to double-taxation, for example, because the money flowing in as revenues was previously subject to sales tax and, prior to that, income tax.

A strong version of such disingenuous reasoning is found in the dead letter from the so-called Kemp Commission, which tried to describe the current tax code's "Bias Against Saving and Investment." Describing a family who has earned $\$ 1,000$, paid $\$ 280$ of that in federal income taxes, and decided to invest the remaining $\$ 720$, the report describes four levels of taxation:

First, [the family] already had to pay income taxes to have the $\$ 720$ to invest. Second, the company in which they invest will generally pay tax at a 35 percent rate on the returns on the amount invested. Third, if the company pays dividends, the family will pay a 28 percent tax on the dividends they receive. Alternatively, if the company retains the after tax income for reinvestment or finds other ways to boost future earnings, the stock price will rise. The future earnings will be taxed, and if the family sells the stock, it will pay a capital gains tax at a 28 percent rate. . . Fourth, if they hold the proceeds of the sale until death, they will be subject to an estate tax that can go as high as 55 percent [National Commission on Economic Growth and Tax Reform, 1996; incorrect use of bold-face in original].

This "quadruple-taxation" is contrasted with the single-taxation that would result if the family had decided to spend the $\$ 720$ on a trip to Disneyland, rather than to save it. ${ }^{11}$ What is not stated is that one could just as easily follow the path of money spent on consumption and claim multiple taxation through similar reasoning: Disney uses the money to pay its employees, who pay Social Security tax and income tax and spend the remaining money on clothes, paying (in most states) sales tax, with the clothing company paying profit taxes and paying its employees, etc. Using this method of counting, it is possible to claim that any flow of money is taxed an infinite number of times.

What makes that type of reasoning wrong, of course, is that the different taxes are being levied due to different economic events. The second and third levels of tax noted above, for example, are not taxes on the $\$ 720$, but on the gains created by the investment of the $\$ 720$. The investment itself is not being re-taxed. Similarly, the inheritance tax is not a continuation of taxation on a flow of income, but a way to 
recapture part of a stock of wealth that would otherwise be passed to heirs who have done nothing-"entrepreneurial" or otherwise-to benefit the economy.

The issue of double-taxation has an important, though limited, role to play in tax debates. However, the issue is currently being overused beyond the point of absurdity. The appropriate questions remain the total amount of taxes levied and the efficiency effects that they cause.

\section{Social Engineering and the Myth of Economic Neutrality}

Perhaps the most striking fact about the proponents of reactionary tax proposals is their failure to recognize that it is not possible to build a tax system that does not "distort" the economy. To listen to their rhetoric, one would think that the economy has been ruined by liberal "social engineers" who insist on loading the federal income tax code with provisions to encourage pernicious behaviors-all the while making life more difficult for entrepreneurs who yearn only for a level playing field on which to compete. This would be comical if it were not so serious. To be blunt, social engineering (or whatever one wants to call it) is both good and inevitable. Everyone does it, not because everyone occasionally gives in to temptation, but because tax policy cannot be about anything but changing social outcomes.

The unchallenged notion that underlies much of the current debate is the idea that the tax code could be made economically neutral, i.e., that people could make decisions not on the basis of tax considerations, but on the basis of their personal preferences and the possibilities of a free marketplace. Once again, this evocative rhetoric has no correlation with reality. To put the point as simply as possible: How can the U.S. government have collected more than $\$ 1.8$ trillion dollars in 1999 (more than one-fifth of personal income) without affecting people's behavior? It is simply not possible.

Neoclassicals define economics as the study of human responses to incentives. As such, every institutional structure is analyzed to find the incentives and disincentives that it embodies. This is particularly true of the tax system-perhaps the most extensively studied incentive system in the entire economy. It is, quite simply, not possible to construct a tax system without incentives and disincentives. No tax system can be "neutral," allowing the economy to move to some state of nature in which all human decisions are led by an invisible hand.

Indeed, even the simplest of tax systems, the "head tax" (where every person pays exactly the same number of dollars per year, no matter what their situation-or what the British call a "poll tax"), creates incentives and disincentives. For example, some people might respond to such a tax by legally "disappearing," that is, by altering their behavior in ways that allow them to pay no tax. This involves making choices to give up some activities that are more likely to result in discovery. 
Moreover, a head tax would create a clear disincentive to having children (although, as always, the magnitude of that disincentive is unclear), since every child would create a tax liability yet would be unable to work for quite a number of years. (Similarly, an exemption for children below a certain age would create other behavioral distortions-lying about the ages of one's children, incentives to throw children out of the household on a certain date, etc.) While these particulars might seem a bit silly to some, they are exactly what those who dream of a perfect tax system claim that they can eliminate.

The effects of taxes on saving is another fertile area of faulty analysis. The current tax code is often asserted to have built-in disincentives to save. (The extensive, and generous, inducements to save are conveniently ignored.) This is one reason why, for example, the tax-preferred treatment of IRAs and pensions is broadly popular among politicians of both parties. ${ }^{12}$ It is also why the tax deduction for interest on consumer debt was phased out-with no discernible impact on the saving rate, which continued to decline.

The crucial point, however, is that the more extreme tax reform proposals wipe out the existing tax code, including all of its disincentives (and incentives) regarding saving. Then, starting from a blank slate, they tax consumption only. This is therefore quite clearly "social engineering, " with the self-appointed tax engineers making the judgment that the economy would be better off with a larger amount of saving than the private economy would naturally produce.

While one could claim that the years of artificially low saving need to be followed by years of artificially high saving (an arguable proposition, at best), this would imply that there would be some point at which consumption should no longer be penalized. However, this is not part of any of the proposals offered to date, and the rhetoric is rather overwhelmingly anti-consumption in general-not just anticonsumption as a short-term corrective.

When it comes to social engineering, of course, it is notable that the one deduction that is allowed in many of the proposed tax systems is the dependent-child exemption. House Majority Leader Armey, indeed, specifically refers to the importance of making the tax system fairer for "families." If we believe that people respond to financial incentives, might we not conclude that this incentive to have children is an attempt at social engineering? After all, many state welfare systems have been changed recently to prevent a minuscule financial incentive from inducing a population explosion among the poor. Why should that not be a similar concern in the general tax code?

It is possible, of course, to accept the "unpleasant" fact that taxation moves people's behavior away from the invisible hand's optima but still believe that these distortions should not be considered consciously when designing tax policy. A tax that distorts behavior is one thing; but when Congress deliberately decides to favor one activity over another, that is "social engineering." This "see no evil" approach, 
which says that distortions are fine so long as we do not know what they are, is bizarre at best. If the economy is not going to be where the non-taxed free market would have it anyway, why not use our admittedly limited analytical powers to see if we can improve matters? This is no longer a matter of moving away from a state of grace, but rather of moving from one creation of fallible humans to another.

The dream of the non-distorting tax is therefore forever to remain unrealized. Of course, this is not to deny that some tax systems are more transparent than others in how they alter behavior. Even if it is not possible to be perfectly neutral, it is at least possible to be simpler than the current tax code. Increased transparency should not be automatically equated with decreased distortion, however. For example, a perfectly transparent tax that would levy a 100 percent rate on all commercial transactions in the state of Texas would hardly lead to small changes in behavior and efficiency.

Therefore, rather than imagining that we can build a non-distorting tax system, the best criteria to evaluate a tax system are (1) what goals are you trying to promote? and (2) are you succeeding? Any analysis of the tax system therefore must proceed from normative assumptions. Since the proponents of trickle-down economics do not want to admit publicly that their real agenda is to shift income upward, they find it more convenient to talk in misleading terms about inefficiency and social engineering. We should not be fooled.

\section{Conclusions}

With the significant exception of a simplified income tax system, every plan to replace the current U.S. federal tax system would move us in precisely the wrong direction. These plans would abandon income taxation entirely in an attempt to solve problems that do not exist, and they are based on a flawed ideal of a neutral tax code. The companion to these plans is an even more misguided set of proposals (some in the form of constitutional amendments) that would severely limit future fiscal policy.

No matter the results of this round of the tax debate, however, when the day is done we can be sure of one thing: someone will have a new proposal the next day. It might even be better than anything we have now.

\section{Notes}

1. While most current tax proposals are clearly motivated by a desire to make the U.S. tax code less progressive (or more regressive), this essay will generally concentrate on the technical and political aspects of various approaches to taxation. (It is impossible not to say something about progressivity along the way, though.) Of course, this does not imply that the effects of the tax code on the distribution of income and wealth are unimportant. 
Quite the opposite. See Buchanan [1998] for a spirited defense of progressivity and some proposals for progressive tax reform.

2. Interestingly, however, no serious proposals have been offered to simplify anything but the federal tax system. Given that there are more than 80,000 taxing authorities in the United States, the tax system's complexities probably have as much to do with interactions among jurisdictions as with the federal tax code itself.

3. An entirely different dimension of the tax code is also under severe attack. Most of the Republican leadership in Congress are committed to repealing the estate tax. This dangerous idea is too broad to be included in the analysis here. However, the interested reader might find it useful to refer to the article mentioned in note 1 for analysis and further references.

4. This, of course, ignores the possibility that the Flat Tax will be so beneficial to the economy that more tax revenue will be realized from lower tax rates. The Laffer Curve, which refuses to die, is a subject for a different essay.

5. Their next dollar of capital income, of course, would not be taxed at all $\multimap$ or, to put it in Hall and Rabushka's terms, it would be taxed at the firm level before it was received as income.

6. This is also a rather stunning omission, given Hall and Rabushka's claim that they have heard, and successfully defended their plan against, every possible argument that can be raised against it.

7. As a practical matter, of course, strong political constituencies will defend much of what makes the tax code complex; and even if we were to succeed in simplifying the current code, new complexities would be added all the time. A more modest understanding of this problem is to view it as a process, not a once-and-for-all solution.

8. These details were last spelled out in 1996. Even with Gephardt's presidential ambitions temporarily on hold, however, something like this plan could emerge again rather soon, with slightly revised details.

9. The extreme example of this is the tax treatment of real estate. According to Hudson [1995], real estate is effectively not taxed at all!

10. There are endless aspects of the transition from the current system to any sweeping alternative system. None of these has been worked out to anyone's satisfaction. Although these issues are beside the point of this analysis, suffice it to say that any claims that any new system would simplify people's lives would come to be seen as cruel jokes as taxpayers tried to negotiate two tax systems and make choices between them. Since the transition period could last as long as 30 years, this is hardly a small issue.

11. Perhaps it would be too much to hope that proponents of a plan to shift the tax burden to working people would not invoke the Disney corporation, which pays its chief executive several hundred million dollars per year.

12. It is odd that neoclassicals forget their own theories when they analyze taxes and saving. As any graduate of an intermediate microeconomics class knows, any change in "prices" can be separated into income effects and substitution effects, with the relative sizes of the two effects unknown. Why, when it comes to saving, is the substitution effect always assumed to be greater than the income effect, so that higher net interest rates always raise saving?

\section{References}

Auerbach, Alan. "Dynamic Revenue Estimation." Joumal of Economic Perspectives (Winter 1996): 141-

158. 
Barton, Joe. 104th Congress, 2d Session. "H. J. RES. 169, Proposing an Amendment to the Constitution of the United States Relating to Taxes." March 28, 1996.

Buchanan, Neil H. "Some Proposals for Progressive Tax Reform." Center for Advanced Macroeconomic Policy (CAMP). Working Paper no. 1998-09, October 1998. 59-76.

. "Taxes, Saving, and Macroeconomics." Joumal of Economic Issues 33, no. 1 (March 1999):

Clark, Peter K. "Tax Incentives and Equipment Investment." Brookings Papers on Economic Activity 1 (1993): 317-47.

Fazzari, Steven M., and Benjamin Herzon. "Capital Gains Taxes and Economic Growth: Effects of a Capital Gains Tax Cut on the Investment Behavior of Firms." The Jerome Levy Economics Institute, Public Policy Brief no. 25, 1996.

Gleckman, Howard, and Mike McNamee. "The Flat Tax May Be Back. Right, Bob?" Business Week (June 10, 1996): 34-35.

Gravelle, Jane. The Economic Effects of Taxing Capital Income. Cambridge, Mass.: The MIT Press, 1994.

Hall, Robert H., and Alvin Rabushka. The Flat Tax. 2d ed. Stanford, Calif.: Hoover Institution Press, 1995.

Hudson, Michael. "Comments at the 'Land, Wealth, and Poverty Conference'." The Jerome Levy Economics Institute, November 2-4, 1995.

Jorgenson, Dale W., and Ralph Landau, eds. Tax Reform and the Cost of Capital: An Intermational Comparison. Washington, D.C.: The Brookings Institution, 1993.

Karier, Thomas. "Investment Tax Credit Reconsidered: Business Tax Incentives and Investments." The Jerome Levy Economics Institute, Public Policy Brief no. 13, 1994.

Merrill, Peter, Ken Wertz, and Shvetank Shah. "Corporate Tax Liability Under the USA and Flat Taxes." Tax Notes (August 7, 1995): 741-745.

National Commission on Economic Growth and Tax Reform. Unleashing America's Potential: A ProGrowth, Pro-Family Tax System for the 21st Century. New York: St. Martin's Griffin, 1996.

Slemrod, Joel B. Statement of Joel B. Slemrod. Testimony before the Senate Finance Committee, Washington, D.C., April 5, 1995. 